\title{
The involvement of foreign citizens in the Czech labour market
}

\begin{abstract}
The Czech Republic is a small, extensively open economy. Its openness is evident also from the involvement of foreign nationals in the Czech labour market. Foreigners may participate in the Czech labour market either as employees or as independent entrepreneurs. There are three facts which, in particular, have influenced the involvement of foreign citizens in the Czech labour market. Firstly, there was the division in 1993 of Czechoslovakia into two independent states, the Czech Republic and the Slovak Republic, after which many Slovak nationals remained to work or carry on business on the territory of the Czech Republic. The second was the admission in 2004 of the Czech Republic to the European Union, which substantially simplified the entry of the citizens of other EU member states to the Czech labour market. The third is the current worldwide economic recession which has been fully displayed in the Czech Republic in the last year. The aim of this article is to analyse how these facts have projected into developments in the number of foreigners in the Czech labour market.
\end{abstract}

Keywords: economic recession, foreigners, Czech Republic, labour market

Introduction

The Czech Republic is a small economy which is strongly interconnected with the outside world. Most often, the openness of an economy is measured with regard to the share of exports and imports in gross domestic product. In 2009, in terms of constant prices, exports represented $98 \%$ and imports $96 \%$ of Czech gross domestic product. However, the interconnectedness of a country with the outside world may also be measured in terms of the participation of foreigners in the national labour market, or according to the participation of nationals in foreign labour markets. This article analyses the participation of foreigners in the Czech labour market.

Foreigners, simply said, can participate in the Czech labour market either as employees or as entrepreneurs. Both these groups can be further divided and their development over time is not symmetrical. Therefore, the first part of the article deals with a detailed classification of foreigners who are economically active in the Czech Republic into particular groups and sub-groups.

The development of foreigners' economic activity in the Czech Republic is tightly connected with three key facts. The second part of the article will deal with these issues. The first is the division of the former Czechoslovakia into two independent states, the Czech Republic and the Slovak Republic, in 1993. The second is the admission of the Czech Republic into the European Union in 2004. Both these issues were linked with extensive legislative changes. This article will demonstrate that these legislative 
changes substantially influenced the development of the number, as well as the structure, of foreigners in the Czech labour market. The third key fact is the economic development of the Czech Republic. During the period in question, the Czech Republic experienced cyclical fluctuations which reached a varying intensity and which did not touch similarly upon all segments of the Czech economy. This article will show that foreigners in the Czech Republic are most involved in those economic segments which experienced the most significant fluctuations.

The third section will focus in detail on economically active foreigners who are employees. Beside the general development, it will analyse the development of individual sub-groups of foreigner-employees, examining the countries of origin and investigating which of the three key facts referred to above had the dominant influence on the development of foreigner-employees in the Czech labour market.

The fourth section will treat in greater detail those economically active foreigners who operate in the Czech Republic on the basis of a trading licence. Again, beside the general trend, it will also deal with the development of various sub-groups of foreignerentrepreneurs, including examining their countries of origin. Also in the case of foreigner-entrepreneurs, statistical analysis will be conducted to determine which of these key issues dominated their development.

The last part of the article briefly mentions the government programmes for attracting foreigners, especially highly qualified ones, into the Czech Republic. With regard to the recent world recession, it will also touch upon programmes for the voluntary repatriation of foreigners from the Czech Republic to their countries of origin.

\section{Classification of foreigners in the Czech labour market}

Foreigners who are economically active in the Czech Republic can be divided, according to the currently valid legislation, into two basic groups:

1. foreigners registered at labour offices. This group can be further divided into:

a) foreigners who are citizens of the member countries of the European Union, the European Economic Area and the European Free Trade Association (EU/ EEA/EFTA). These foreign citizens and their family members are not treated as foreigners by the current legislation; therefore, in the Czech labour market they have a position equal to that of Czech citizens. Citizens from these countries do not need work permits and are allowed to carry out all professions, excluding those for which legal regulations require citizenship of the Czech Republic. Employers of these foreigners have to report them to the labour office

b) foreigners who need neither a work permit nor a Green Card, although they are not citizens of member countries of EU/EEA/EFTA. Foreigners belonging to this group are stipulated by the Act on Employment and include, for example, people who have been granted a permanent residence permit in the Czech Republic; people employed on the basis of an international agreement which is binding on the Czech Republic; those who are accredited in the field of the media; those who are students up to 26 years of age, teachers and researchers, sportsmen and women, etc. All these groups of foreigners have to inform the relevant labour office of their activities 
c) foreigners who need a work permit or Green Card. The Green Card is a permit for permanent residence in the Czech Republic for employment purposes. The Green Card, however, is issued only to those citizens of a group of chosen countries which are not members of the European Union and who have a qualification which is demanded in the Czech Republic.

2. foreigners undertaking business on the basis of a trading licence. Foreigners may run a business either with a foreign legal identity or they may establish a legal identity, or an organisational component of a foreign company, in the Czech Republic. Unless the Act stipulates otherwise, foreigners may run a business based on the same conditions as citizens of the Czech Republic.

This group can be further divided into:

a. foreigner-entrepreneurs from EU/EEA/EFTA. Natural persons from these countries do not have to possess a residence permit to receive a trading licence

b. foreigners from other countries, who do need a residence permit to get a trading licence.

Information about the amount and structure of foreigner-employees is gathered from the respective labour offices by the Ministry of Labour and Social Affairs of the Czech Republic; while information about the amount and structure of foreigner-entrepreneurs is collected from the respective trading licence offices of the Ministry of Trade and Industry of the Czech Republic.

The development of the total economic activity of foreigners, as divided into these two basic groups, in the period of 1997 up to the end of the first half of 2010 is displayed in Figure 1. In 1997 in the Czech Republic, there were more than 194000 economically active foreigners. In the following two years, a slight decline can be observed followed by steady growth until 2008. At the end of 2008, there were c. 362000 economically active foreigners in the Czech Republic. If we take 2003, i.e. one year before the accession of the Czech Republic to the European Union, as a base year, the amount of economically active foreigners more than doubled up to 2008. 2009 marked a reversal, which continued also in the first half of 2010. From the end of 2008 until June 2010, the amount of economically active foreigners decreased by $15 \%$.

If we take into account that the total workforce in the Czech Republic within the observed period fluctuated between 5.1 and 5.2 million people, the portion of foreigners in the total workforce ranged from $2.9 \%$ in 1999 to $6.9 \%$ in 2008. 
Figure 1 - Economic activity of foreigners in the Czech Republic

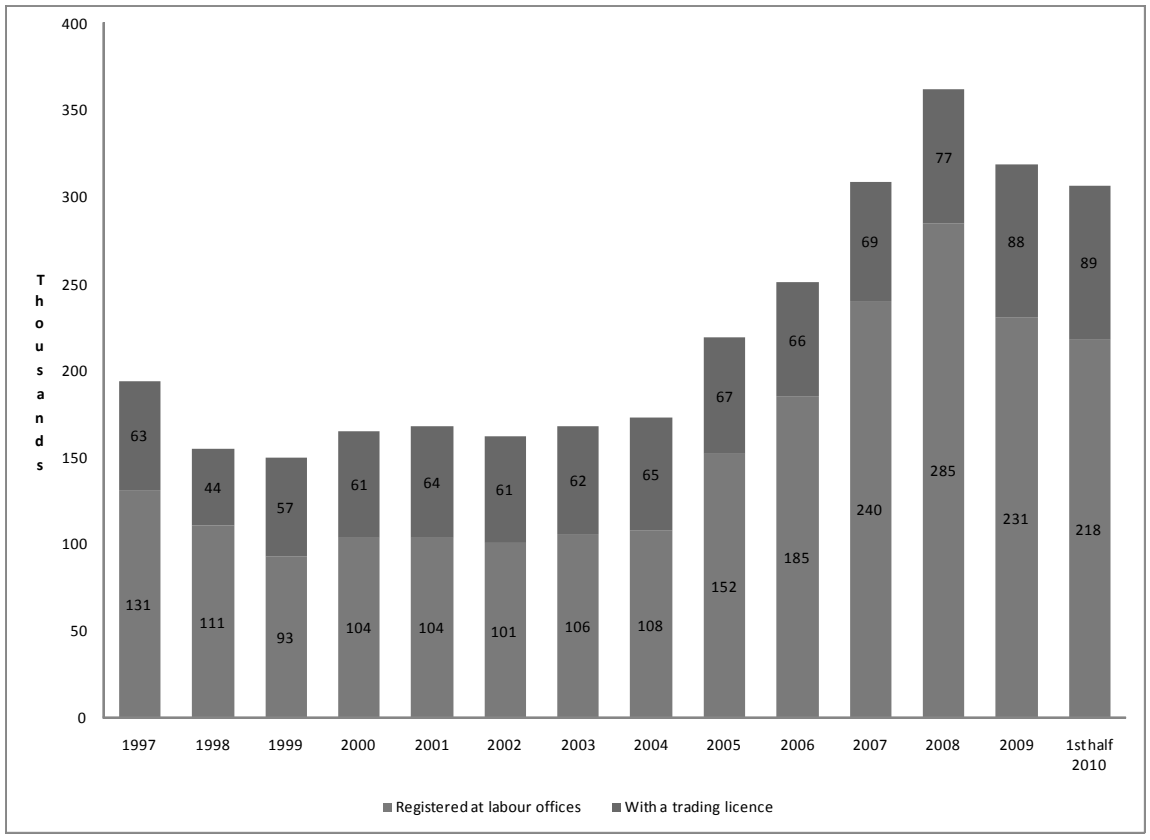

Source: Czech Statistical Office (ČSÚ, 2010)

Key factors influencing developments in foreign workers in the Czech labour market

The economic activity of foreign workers in the Czech Republic is, of course, influenced by a number of diverse factors. This article focuses on, from our point of view, the three key ones: the disintegration of the common state of Czechoslovakia into two independent states; the accession of the Czech Republic to the European Union; and the economic development of the Czech Republic.

The common federative state of the Czechs and Slovaks originated after World War 1 in 1918. During the existence of Czechoslovakia, the labour migration of Czechs into Slovakia, and of Slovaks into the Czech part of the country, was common. Very often, mixed marriages were concluded. A key advantage was that, even though both nations spoke their own language, the languages were very close and the inhabitants of the Czech and Slovak parts of Czechoslovakia were able to understand each other. After World War 2, the then Czechoslovakia became part of the bloc of socialist countries. This had a substantial impact on the participation of foreigners in the Czechoslovak labour market.

Based on inter-governmental agreements, foreigners from other countries of the socialist camp worked in the then Czechoslovakia. Boušková (1998) confirms that the largest groups in the 1970s and 80s were citizens of the Polish People's Republic, of 
whom more than 20000 were employed on a long-term basis in Czechoslovakia (in 1974); and citizens of the Vietnamese People's Republic, who were more than c. 27000 (in 1983). In addition to the employment of foreigners, the professional preparation of pupils, apprentices and employees from the former socialist countries was common at that time. In this professional preparation, as well as in employment in Czechoslovakia, participated citizens of the Cuban Republic, Hungary, Mongolian Republic, Angolan People's Republic, People's Democratic Republic of Laos and Korean People's Democratic Republic. After 1990, these inter-governmental agreements were called in by the Czechoslovak government. This short recourse to history should explain why also nowadays among the most numerous foreigners who are economically active on the Czech territory belong citizens of these countries, particularly of Poland and Vietnam. Citizens of these countries frequently learned the Czech language and established various contacts which facilitated easier participation in the Czech labour market.

At the end of 1992, Czechoslovakia was dissolved. On its basis, two independent states - the Czech Republic and the Slovak Republic - were built. After the demise of the common state, the position of citizens of the Slovak Republic did not in fact change. Based on an inter-governmental agreement about the mutual employment of citizens, free movement of the labour force existed de facto between the two countries. In contrast to foreigners from other countries, Slovakian citizens were allowed to work in the Czech Republic without the requirement of a work permit. The only obligation was that the employer in the Czech Republic had to report the employment of citizens of the Slovak Republic to the respective labour office.

During the 1990s and at the beginning of the new millennium, i.e. before the accession of the Czech Republic to the European Union, the Czech Republic had already concluded (or ceded back from the former federation) inter-governmental agreements with other countries on the mutual employment of citizens. Advantageousness from the point of view of the situation in the Czech labour market was a particular contributor to this process. Inter-governmental agreements were concluded, for example, with Poland, Ukraine, Germany, Vietnam, Russian Federation, Mongolia and Bulgaria.

Apart from these inter-governmental agreements on the mutual employment of citizens, the number of foreigners was influenced by a range of legislative adjustments. These legislative changes influenced foreigner-employees as well as foreigners with a trading licence. In brief, it can be said that these legislative changes were designed to limit the accession of foreigners (from outside the European Union, Slovakia, etc.) to the Czech labour market, although one of the other reasons was also a worsening economic situation, which will be dealt with later. Based on the legislative adjustments made during this period, the conditions for the issue of work permits to foreigners were tightened; the conditions on the basis of which asylum seekers may apply for work permits were changed; the conditions of the presentation of documents for entrepreneurs were tightened; and the conditions for receiving long-term stay permits for the sake of carrying on business were toughened.

A reversal in the access of foreigners to the Czech labour market was represented in the accession of the Czech Republic to the European Union. From this moment, foreigners coming from the member states of the European Union, the European Eco- 
nomic Area and the European Free Trade Association are not treated as foreigners, as has already been mentioned.

The development of economic activity among foreigners in the Czech Republic undoubtedly reflects the impact within the Czech Republic of the global economic situation. Figure 2 portrays the changes in the Czech Republic's real gross domestic product and yearly unemployment rates in the period from 1996 to 2009 .

After a relatively solid growth in real GDP in 1996, connected with a low unemployment rate, the Czech economy underwent a slight recession in the following two years. To the rapidly growing external imbalance of the Czech economy, the Czech National Bank (the central bank of the Czech Republic) reacted firstly by tightening its monetary policy. The government followed the central bank with a reduction of its expenditure. In addition, in the spring of 1997 there were speculative attacks on the Czech koruna, which led to the abandonment of the fixed exchange rate.

Real GDP displayed positive growth after 1999 but, in the beginning, these increases were so low that they were not able positively to influence the labour market. The unemployment rate gradually rose, reaching a peak in 2004. At the end of this year, there were c. 570000 unemployed people in the Czech Republic and the unemployment rate was above $10 \%$.

In the 2005-2007 period, the growth in real GDP exceeded $6 \%$. This rapid growth was reflected positively in the labour market with a decrease in the unemployment rate. In the following year, the growth in real GDP slowed to $2.5 \%$. In the labour market, however, inertia led to a decrease in the unemployment rate to $5.5 \%$.

In the second half of 2008, the slowdown in the Czech economy as a result of world economic trends was already evident. During 2009, the Czech economy was in recession: real GDP sharply fell by more than $4.1 \%$ and the unemployment rate increased. Preliminary data for the first half of 2010 suggest, however, that there has been something of a recovery, with a gradually improving economic situation: in the first six months, real GDP increased by almost $2 \%$, although the unemployment rate still remains above $8 \%$. 
Figure 2 - The development of GDP and the rate of unemployment in the Czech Republic

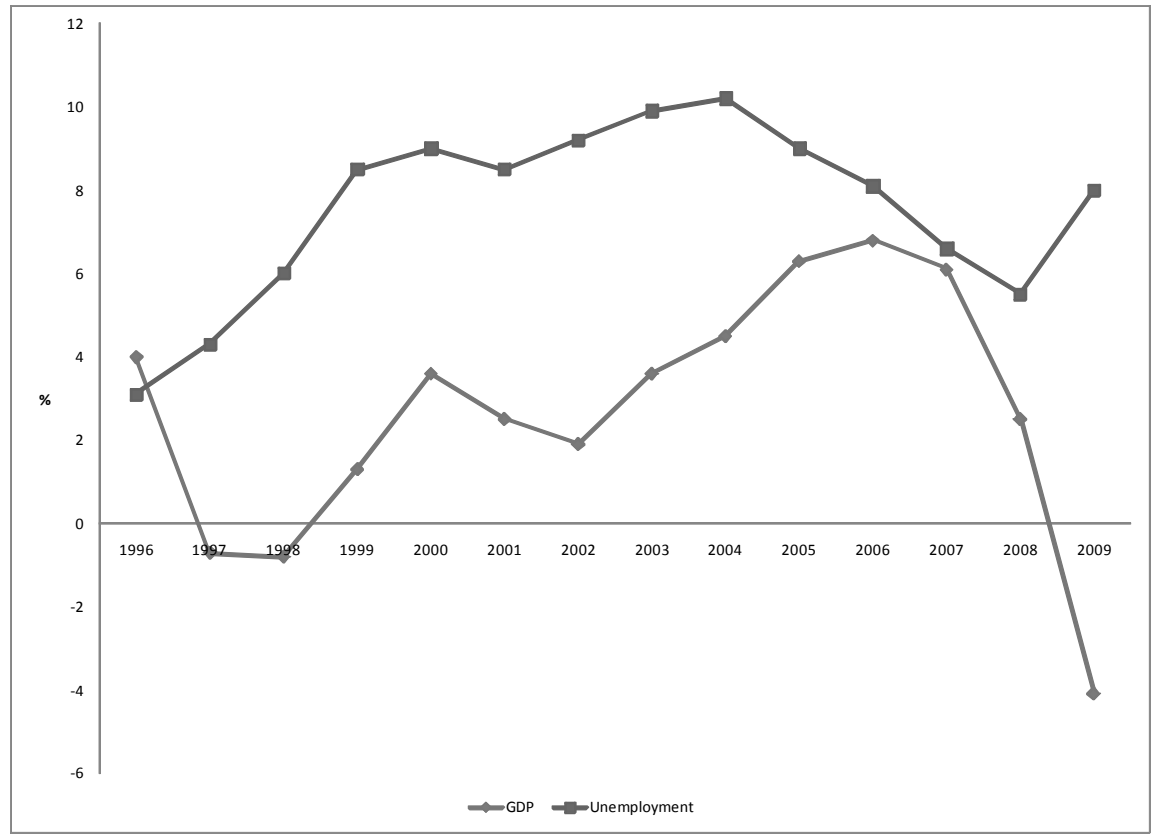

Source: Czech Statistical Office (ČSÚ, 2010)

To evaluate the repercussions of economic swings on the economic activity of foreigners, it is worthwhile to investigate in detail the development of two branches of the Czech economy, namely manufacturing and construction. As will be explained later, the largest number of foreigner-employees is employed in these two sectors. Therefore, fluctuations of production in manufacturing and construction have a substantial impact on the entire development of the employment of foreigners in the Czech Republic.

Figure 3 displays the annual percentage change in production in the manufacturing and construction sectors in constant prices from the beginning of 2008 up to the first half of 2010. A decline in manufacturing had already begun in October 2008 and continued until November of the following year. In the first two months of 2009, production in manufacturing decreased on the same period the year before by a record $26 \%$.

A revival of the industry has been apparent since the last month of 2009 while, in the second quarter of 2010, production in manufacturing in the Czech Republic grew by a double-digit number. The cause of such an overwhelming rate of growth is, of course, also an effect of the low basis for comparison from the previous year.

Production in the construction sector decreased between October 2008 and March 2009 , but its decrease over this period was not as deep as in the case of production in 
manufacturing. A positive role here was played by governmental expenditure on infrastructure and housing construction. After stagnation during the rest of 2009, production in the construction industry at the beginning of 2010 slumped in comparison with the prior year. Negative year-on-year changes in construction continued across the whole first half of 2010.

Figure 3 - The development of manufacturing industry and construction in the Czech Republic (2008-2010)

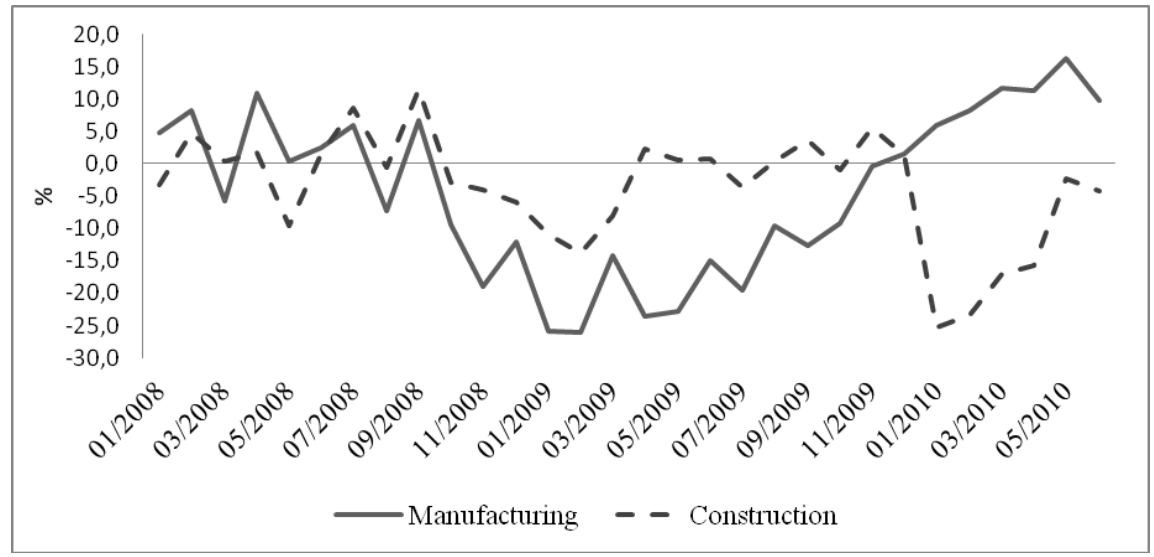

Source: Czech Statistical Office (ČSÚ, 2010)

Foreigner-employees

Following the accession of the Czech Republic to the European Union, the group of foreigner-employees may be divided into three sub-groups:

- foreigners from EU/EEA/EFTA countries

- foreigners who do not need a work permit although they are not from EU/EEA/ EFTA countries

- foreigners who need a work permit.

Owing to methodical comparability and also because of the availability of detailed data, the following part will focus on a period starting in 2004. In particular, the period of recent economic decline, i.e. the period from 2008 up to the first half of 2010, will be analysed in greater detail. Figure 4 shows the division of foreigner-employees into the various sub-groups. 
Figure 4 - Foreigner-employees

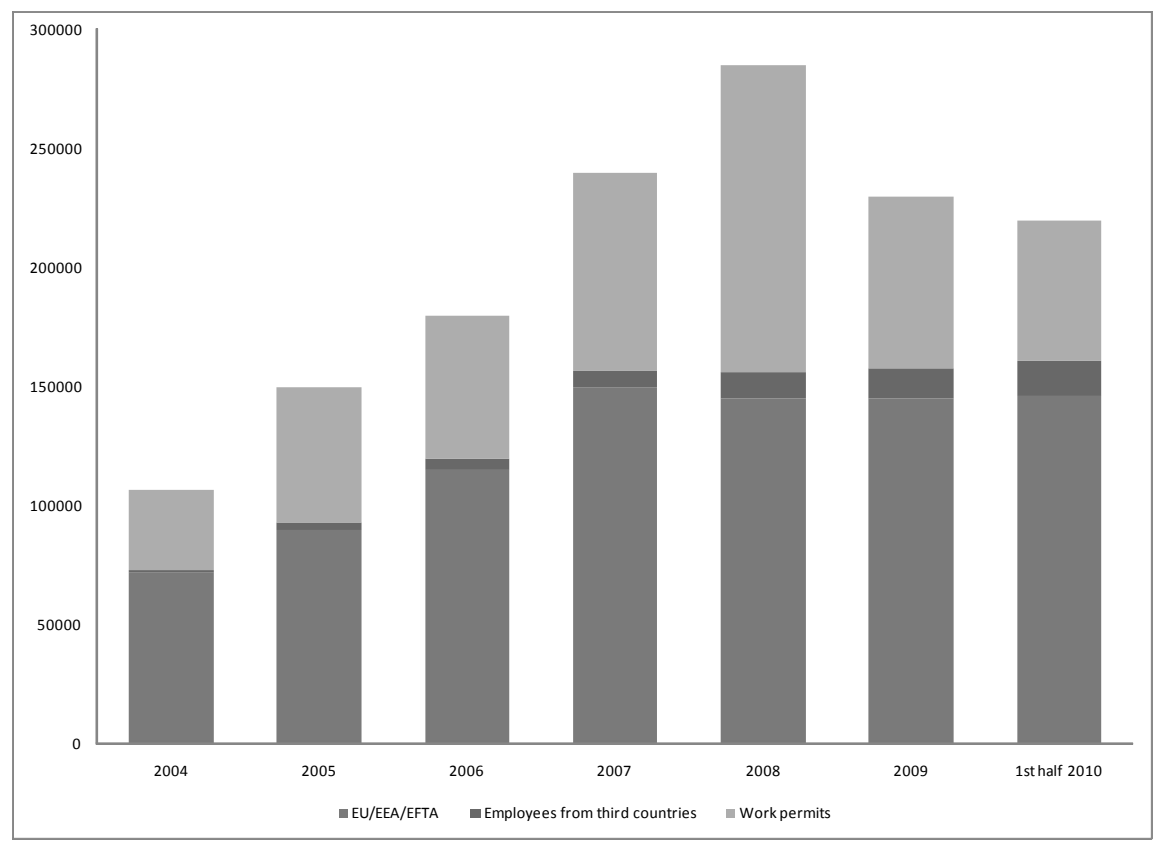

Source: Czech Statistical Office (ČSÚ, 2010)

At the end of 2004, almost 108000 foreigners were employed in the Czech Republic. More than $67 \%$ of the total came from EU/EEA/EFTA countries; just under $32 \%$ possessed a work permit; and the remaining one per cent were foreigners employed without the need for a work permit despite not being from EU/EEA/EFTA countries. Men represented a $62 \%$ share of the total number of foreigner-employees, and women $38 \%$.

The improving economic situation, linked to the demand of domestic firms for employees, led to a relatively fast growth in the total number of foreigner-employees. The peak was in 2008. As at the last day of 2008, 284500 foreigners were employed in the Czech Republic. In comparison with the end of 2004, the total amount of foreigner-employees grew by more than 176000 , i.e. by $163.5 \%$. The number of foreigners coming from EU/EEA/EFTA countries grew in the 2004-2008 period by more than 68000 , i.e. by $93 \%$. This growth was, apart from the improving economic situation in the Czech Republic, also influenced by the entry of Bulgaria and Romania to the European Union; this represented 8600 foreigners newly counted among EU/EEA/ EFTA countries.

The number of foreigners who do not need a work permit despite not being from EU/EEA/EFTA countries, grew by more than 19 times in the same period. In this subgroup, the number of foreigners coming from Ukraine, Vietnam and Russia grew the 
most. The number of foreigners who need a work permit grew in the same period (to the end of 2008) by almost 95000 , i.e. by $275 \%$.

By the end of 2008, the first signs of the world economic recession had become apparent in the Czech Republic. Production decreased, particularly in the course of 2009, and firms, facing a slump in orders (contracts), gradually dismissed their employees. Among the first who were forced to leave their work positions were foreign workers. In particular, large firms in the Czech Republic often used so-called agency employees, who are not primary employees of the respective firm but hired from agencies; therefore, the dismissal of such employees is not costly for the firms because they do not have to pay compensation, often to an amount of several monthly wages, while a notice period, of course, also does not apply. Among agency employees, foreigners were often dominant.

From the end of 2008 up to the first half of 2010 , the number of foreigner-employees in the Czech Republic decreased in total by c. 66 000, i.e. by $23 \%$. The total number of foreigners employed in the Czech Republic as at the end of June 2010 was more than 218000 . The number of foreigner-employees coming from EU/EEA/EFTA countries slightly declined during the same period, by c. $1 \%$; while, during the first half of 2010 , a slight increase is again apparent. In the same period, the number of foreigner-employees who do not need a work permit and who are not from EU/EEA/EFTA countries increased by four thousand people, i.e. by almost $35 \%$. However, in the case of foreigner-employees who do need a work permit, a rapid decline is observable during this same period, of almost 70000 , i.e. by more than one-half.

An interesting view can also be obtained if we look at the structure of foreigneremployees according to the country of their origin. Figure 5 displays the structure of foreigner-employees in mid-2010, while Table 1 reports on the changes in the number of foreigners between the end of 2008 and the first half of 2010 for the ten countries from which there are the most people working in the Czech Republic.

At the end of the first half of 2010, citizens of Slovakia represented $45 \%$ of foreigner-employees (218 500). Table 1 shows that the number of Slovak citizens who are employed in the Czech Republic declined between the end of 2008 and the first half of 2010 by 1600 in total, i.e. by c. $1.6 \%$. The dominant share of Slovakians in the total number of foreigner-employees has already been explained in the previous part of the article: that Slovakia previously formed a common state with the Czech Republic; both countries are neighbouring ones and, therefore, good transport connections exist; and, in fact, there is no language barrier.

The second largest group is formed from among citizens of Ukraine. As at the end of the first half of 2010 , Ukrainian citizens represented $22 \%$ of all foreigner-employees. However, it is apparent from Table 1 that their number has decreased by more than 32000 , or $40 \%$, since the end of 2008 . The reason for this development is, in particular, that Ukraine citizens working in the Czech Republic are in low-skilled positions and, in addition, as Table 2 shows, especially in construction and manufacturing, i.e. in those branches which were most affected by the recession. In most cases, Ukrainian people working in the Czech Republic do so on the basis of a work permit. After losing their jobs and, therefore, also their work permits, they faced enforced departures from the 
Czech Republic, resulting in some Ukrainians applying for trading licenses, as will be explained in greater detail in the following section of this article.

The third largest group of foreigner-employees in the first half of 2010 was formed from among citizens of Poland. From the end of 2008, their total declined by almost $8 \%$.

Other than people from Slovakia, Ukraine and Poland, a notable share in the total number of foreigners working in the Czech Republic in the first half of 2010 was taken by citizens of Bulgaria, Moldova and Romania.

In total, people from these six countries represented $82 \%$ of the number of foreigner-employees. Hence, people from other countries made up just $18 \%$ of the total.

\section{Figure 5 - Country of origin of foreigner-employees as at 30 June 2010}

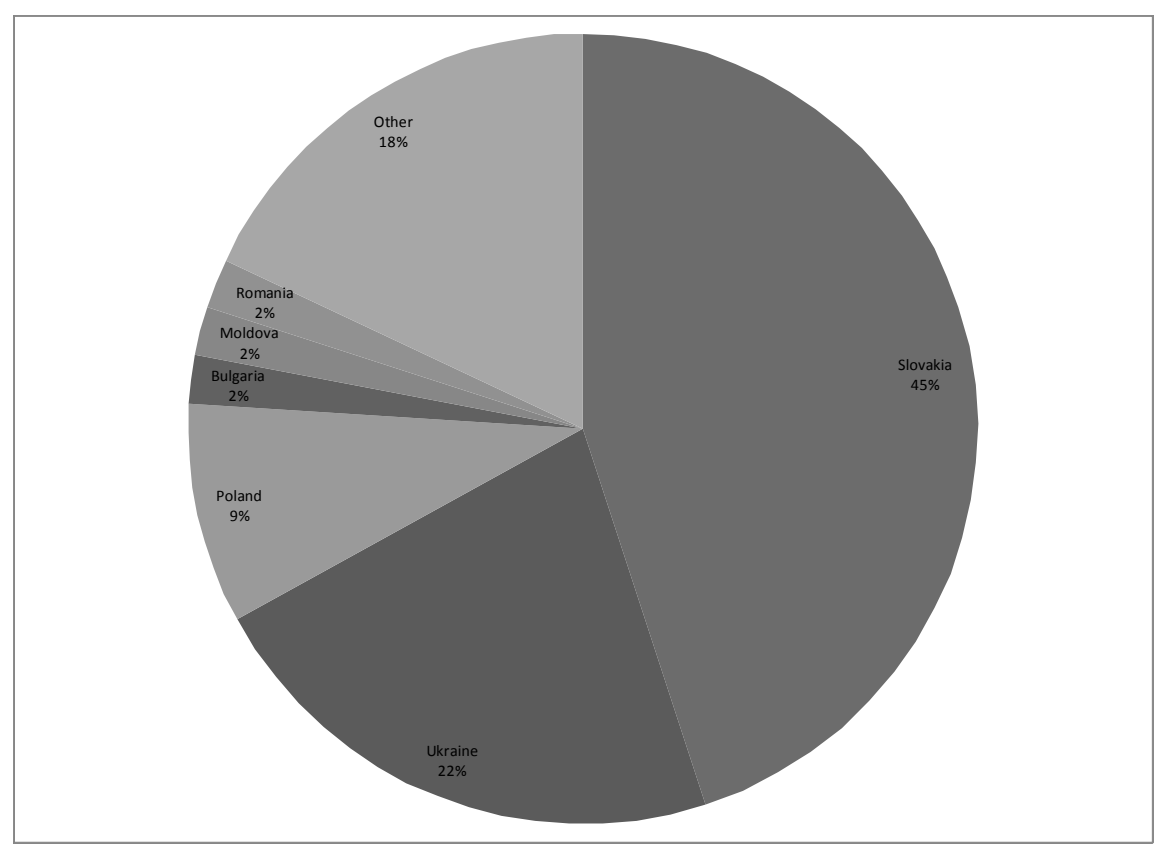

Source: Czech Statistical Office (ČSÚ, 2010), own calculations 
Table 1 - Foreigner-employees according to country of origin

\begin{tabular}{|l|l|l|l|l|}
\hline & $\mathbf{2 0 0 8}$ & $\mathbf{2 0 0 9}$ & June 2010 & $\begin{array}{l}\text { Difference } \\
\mathbf{2 0 0 8} / \text { June }\end{array}$ \\
\hline $\begin{array}{l}\text { Foreigners registered in labour } \\
\text { offices - total }\end{array}$ & 284551 & 230709 & 218462 & -66089 \\
\hline EU/EEA/EFTA & 141101 & 139315 & 139879 & -1222 \\
\hline Slovakia & 100223 & 98192 & 98612 & -1611 \\
\hline Ukraine & 81072 & 57478 & 48654 & -32418 \\
\hline Poland & 20680 & 20278 & 18996 & -1684 \\
\hline Moldova & 8635 & 5706 & 4267 & -4368 \\
\hline Bulgaria & 5108 & 4578 & 5026 & -82 \\
\hline Mongolia & 12990 & 4205 & 3554 & -9436 \\
\hline Russian Federation & 3314 & 3612 & 3518 & 204 \\
\hline Vietnam & 16254 & 3670 & 3329 & -12925 \\
\hline Romania & 3605 & 3780 & 4352 & 747 \\
\hline Germany & 2774 & 2989 & 2924 & 150 \\
\hline
\end{tabular}

Source: Czech Statistical Office (ČSÚ, 2010), own calculations

It can be seen from Table 1 that the greatest proportionate decrease between the end of 2008 and the first half of 2010 was among citizens of Vietnam, Mongolia and Moldova. The amount of foreigner-employees from Vietnam in the period under observation decreased by $80 \%$; from Mongolia by $72 \%$; and from Moldova by $50 \%$. Mongolians and Moldovans work mostly as supporting and unskilled employees, in some cases as servicers of machines and equipment in the factories. Like some of the dismissed citizens of Ukraine, some of the dismissed citizens of Vietnam and Moldova also applied for trading licences to avoid being returned to their countries of origin.

In contrast, Table 1 also indicates that, in the period under observation, foreigneremployees from Romania, Russian Federation and Germany increased.

Table 2 indicates how important are the manufacturing and construction branches from the point of view of foreigners registered with labour offices in the Czech Republic. It was mentioned in a previous part of this article that both of these branches were substantially affected by the economic recession. For various countries, Table 2 shows the absolute total number of foreigners employed in the respective branch, as well as the share of foreigners in each branch as a percentage of the total number of foreigner-employees who come from each country. The data in Table 2 portray the situation as at the end of 2008 , i.e. at the beginning of the economic recession in the Czech Republic. 
Out of a total of 284500 foreigners registered with labour offices, almost 103000 , or $36.2 \%$, worked in manufacturing industry, while 69000 , or $24.3 \%$, was employed in construction. Hence, at the end of 2008, these two branches took up $60 \%$ of all foreigners.

Out of the total number of foreigners from Slovakia in the Czech Republic at the end of 2008, 36.8\% worked in manufacturing and $13.4 \%$ in construction. The total number of foreigners from Slovakia decreased only slightly between 2008 and 2009, by just $2 \%$. In the same period in manufacturing and construction, however, the number declined by more than $12 \%$. This means that the amount of foreigners from Slovakia employed in other branches of the economy had to rise. Foreigners from Slovakia have a specific position in the Czech Republic. In comparison with foreigners from other countries, those from Slovakia are involved more heavily in positions with higher skill requirements, and their involvement in managerial positions, research and teaching posts, and also in positions in healthcare, is common. In contrast, those in unskilled and supporting positions, which were affected most by the slowdown in the Czech economy, account for less than $20 \%$ of the total.

An opposite example is represented by foreigners coming from Ukraine. Out of the total number of foreigners from Ukraine in the Czech Republic at the end of 2008, $21.8 \%$ worked in manufacturing and $51.9 \%$ in construction. In total, between 2008 and 2009 , the number of foreigners from Ukraine dropped by $30 \%$, while this downwards trend continued in the first half of 2010. In the same period in manufacturing and construction, however, the number declined by more than $40 \%$. Sixty five per cent of foreigners from Ukraine in the Czech Republic are employed in an unskilled or support capacity. This is also the reason for such a large decrease in their total during the economic recession.

Similarly, at the end of 2008 construction and manufacturing saw a high share of foreigners coming from the other countries listed in Table 2, excluding those from Russia. Foreigner-employees from Russia in the Czech Republic are involved in other branches, and it is no exception that they work in highly skilled positions. 
Table 2 - Foreigner-employees in manufacturing industry and construction in 2008

\begin{tabular}{|l|l|l|l|l|}
\hline & \multicolumn{3}{|l}{ Manufacturing } & Construction \\
\cline { 2 - 5 } & No. & \% & No. & \% \\
\hline Slovakia & 36920 & 36.8 & 13424 & 13.4 \\
\hline Ukraine & 17665 & 21.8 & 42114 & 51.9 \\
\hline Poland & 10949 & 52.9 & 1832 & 8.9 \\
\hline Vietnam & 13840 & 85.1 & 520 & 3.2 \\
\hline Mongolia & 9575 & 73.7 & 1421 & 10.9 \\
\hline Moldova & 2670 & 30.9 & 3735 & 43.3 \\
\hline Bulgaria & 2087 & 40.9 & 490 & 9.6 \\
\hline Romania & 1931 & 53.6 & 334 & 9.3 \\
\hline Russia & 478 & 14.4 & 421 & 12.7 \\
\hline All countries & 102922 & 36.2 & 69076 & 24.3 \\
\hline
\end{tabular}

Source: Czech Statistical Office (ČSÚ, 2010), own calculations

The impact of the economic recession on the number of foreigner-employees

It was mentioned earlier that developments in the number of foreigners registered with labour offices are connected with the state of economic development in the Czech Republic. The worldwide economic recession, which also struck the Czech economy, has led to significant changes in the Czech labour market. Figure 2 above portrayed the connection between the development of gross domestic product and the rate of unemployment in the Czech Republic. Apart from changes in the unemployment rate, however, there have also been changes in the amount of vacancies available. During 2005-2007, when the Czech economy reached record growth rates and the unemployment rate was declining, the Czech economy, according to the conclusions of the Ministry of Finance of the Czech Republic, faced a positive product lag (Ministerstvo financí České republiky 2010: 25). In this period, demand for the production of firms was rising and, thus, firms needed to hire new employees. In the labour market, however, there was a shortage of domestic employees and the number of unoccupied job opportunities rose. Hiring employees from abroad thus became extremely important and, in addition to the direct employment of foreigners by firms themselves, the abovementioned employment of foreigners via agencies became common: agencies provided large companies with thousands of foreign employees.

To evaluate the influence of the economic cycle on the employment of foreigners, it is worthwhile analysing the links between unemployment and the numbers of vacancies and foreigner-employees. This relationship is depicted in Figure 6. 
Figure 6 - Foreigner-employees, total unemployment and vacancies in the Czech Republic, 2008 - June 2010

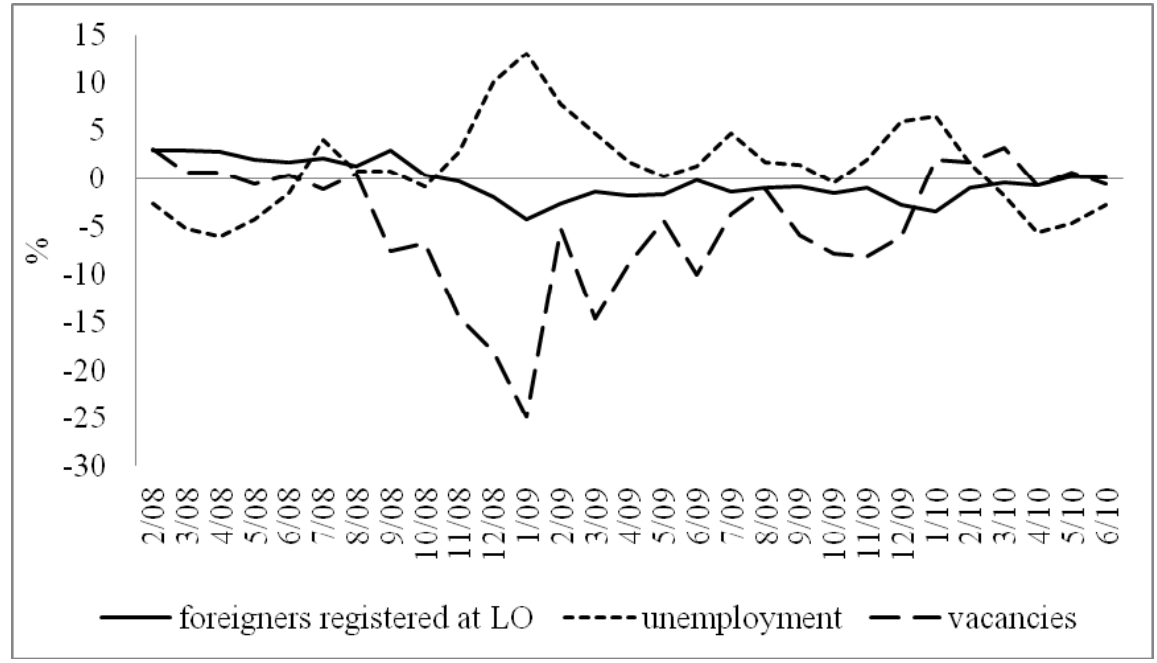

Source: Czech Statistical Office (ČSÚ, 2010), own calculations

Figure 6 illustrates the month-by-month percentage changes in the numbers of foreigners registered with labour offices, of the registered unemployed and of job vacancies from the beginning of 2008 up to the middle of 2010. All this information is derived from data published monthly by the Ministry of Labour and Social Affairs of the Czech Republic.

The unemployment rate in the Czech Republic was still decreasing at the beginning of 2008 (here, the traditional seasonal fluctuation during the spring months is also evident in the trend). In January 2008, the unemployment rate was $6.1 \%$ and, up to the June of that year, it decreased by 1.1 percentage points to $5.0 \%$. After that, the unemployment rate began to rise. After initial hesitation, firms shifted their sales problems to the shoulders of employees, starting significant redundancy programmes. The unemployment rate grew every month, apart from October 2009, until February 2010 when it reached the level of $9.9 \%$. The number of unemployed people registered with labour offices in February 2010 increased on an annual basis by almost 155000 . For the following four months of 2010, the unemployment rate dropped, albeit very slowly.

The worsening situation in the Czech labour market at the beginning of the recession is also evident from the trends in vacancies. In June 2008, the number of vacancies approached 150000 but, by the end of 2009, it equalled only 30000 . At the beginning of 2010, the number of vacancies slightly grew on a month-to-month basis but, in the following months of the first half of the year, it stayed virtually unchanged.

It is apparent from Figure 6 that, in the period under observation, the increase in the number of the unemployed and the reduction in vacancies were connected with the 
gradual decrease in the number of employed foreigners registered with labour offices, which have been on the decrease since November 2008. In October 2008, the total number of foreigners registered with labour offices represented more than 291000 ; in October 2009, there were only c. 240000 and, in June 2010, only c. 218000.

The relationships between the number of foreigners registered with labour offices and the unemployment rate, as well as the number of vacancies, which is observable from Figure 6, can also of course be expressed by means of correlation analysis. For the period in question, the correlation coefficient between the number of foreigneremployees and the unemployment rate equals -0.71 and between the number of foreigners and vacancies, 0.5 . From these calculated correlation coefficients, one can imply that a relatively strong interdependence exists between the number of foreigneremployees and the unemployment rate. With an increase in the rate of unemployment, the number of foreigners registered with labour offices decreases significantly. A moderately strong positive correlation also exists between foreigner-employees and available vacancies; with a decrease in vacancies, the number of foreigners registered with labour offices also declines.

These correlation coefficients were computed from data for the period from the beginning of 2008 up until the end of the first half of 2010. Calculations of correlations for longer periods are also, however, available. Löster (2010: 74-79) attempted in his article to portray the interdependence between the number of foreigners registered with labour offices and the unemployment rate, and also the trends in vacancies, over the 1997-2009 period in the Czech Republic. For this purpose, he relied on data sorted according to the various regions of the Czech Republic. His calculations indicate a very strong interdependence between the number of foreigner-employees and the rate of unemployment. This interdependence can be modelled by a regression hypothesis, and the correlation coefficient for the whole period equals 0.83 . Strong, almost straight line, interdependence also exists between the number of foreigner-employees and vacancies, with a correlation coefficient of 0.97 .

Foreigners with a valid trading licence

Following the accession of the Czech Republic to the European Union in 2004, foreigner-entrepreneurs can be divided into two groups:

- foreigners coming from EU/EEA/EFTA member countries

- citizens coming from other countries.

To be able to run a business in the Czech Republic, foreigners must obtain a trading licence (as do citizens of the Czech Republic). Foreigners who do not come from EU/ EEA/EFTA countries must, in addition, obtain a residence permit alongside a trading licence.

For reasons of methodological comparability, and also because of the availability of detailed data, this section will focus on the period starting from 2004, while the period of the recent economic slow-down, i.e. from 2008 until the end of the first half of 2010, will subsequently be analysed in further detail. Differently from foreigneremployees, for whom monthly data are available, data for foreigner-entrepreneurs is only available for particular years, but there are also some figures available on a quarterly basis. 
Figure 7 displays the recent trends in the number of entrepreneurs in the Czech Republic, divided into two groups according to country of origin. Between the accession of the Czech Republic to the European Union and the end of this period, the number of foreigner-entrepreneurs grew continuously, with the exception of 2006 when it slightly decreased. From 2004 up to the middle of 2010, the number of foreignerentrepreneurs grew by more than 24000 (by $37 \%$ ) to a total of 89500 . The number of foreigner-entrepreneurs from EU/EEA/EFTA member countries grew in this time by 4600 (by $35 \%$ ), while the number of foreigner-entrepreneurs from other countries increased by 19600 (by $38 \%$ ).

It has already been mentioned that foreigner-entrepreneurs need to obtain a trading licence. Entrepreneurs in the Czech Republic, regardless of whether they are citizens of the Czech Republic or of other countries, may own more than one trading licence. Pavelka (2010: 86-91) refers to the number of trading licences per foreigner decreasing during the past few years, and being lower for foreigners than for Czech citizens. A substantial decrease in the number of trading licences per entrepreneur occurred in 2008, however, when a single independent licence was introduced encompassing eighty fields of activity instead of the 125 independent licences which existed up to then.

\section{Figure 7 - Foreigner-entrepreneurs}

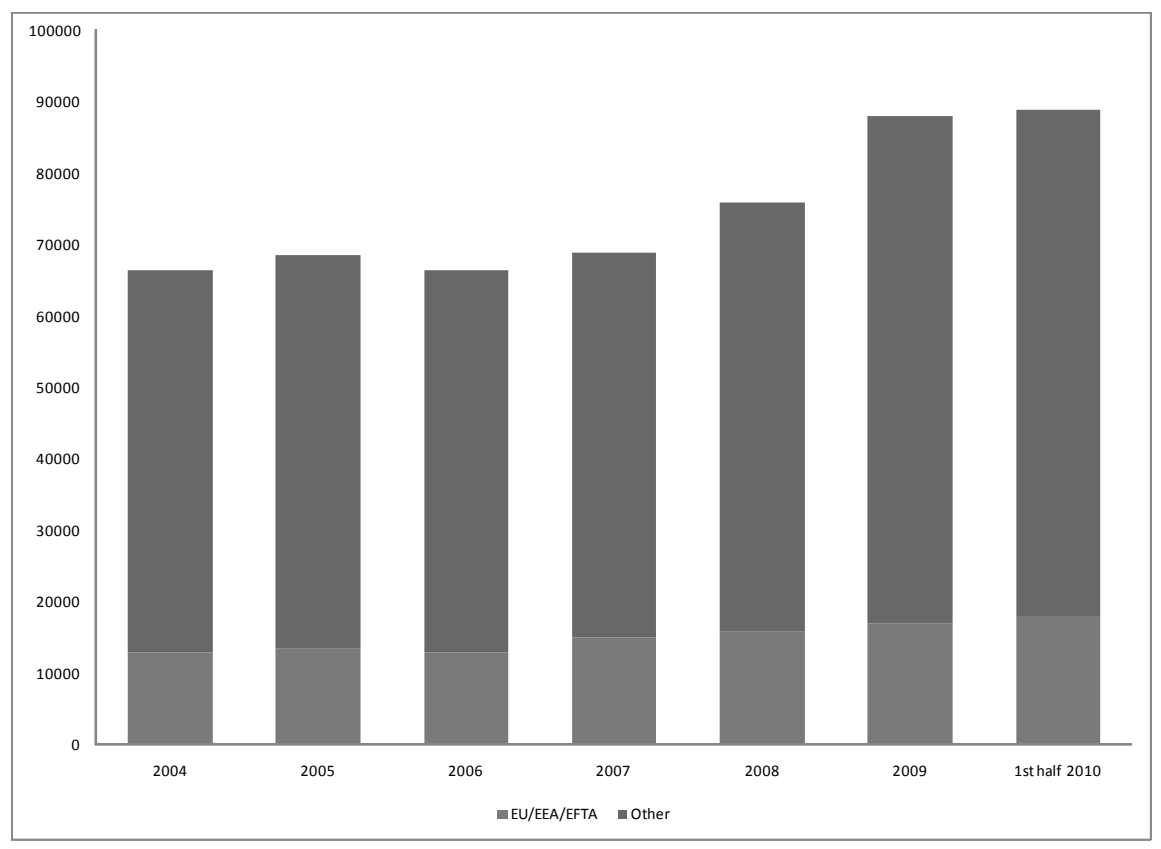

Source: Czech Statistical Office (ČSÚ, 2010) 
Similar to foreigner-employees, it is also interesting to have a more detailed look at the countries of origin of foreigner-entrepreneurs. Figure 8 depicts the structure of foreigner-entrepreneurs as at the end of the first half of 2010, while Table 3 summarises the changes in the number of foreigners between the end of 2008 and the middle of 2010 for the ten countries from which come the most foreigners running businesses in the Czech Republic.

The first significant difference between entrepreneurs and employees is the differing shares of foreigners from EU/EEA/EFTA member countries in the total. Foreignerentrepreneurs coming from EU/EEA/EFTA countries as at the middle of 2010 represented less than $20 \%$ of the total number of foreigner-entrepreneurs, which is much less than for foreigner-employees: foreigner-employees from EU/EEA/EFTA member countries to the same date represented $64 \%$ of the total number of foreigner-employees.

There may be a number of reasons for this situation. One explanation may be that there are no administrative complications (costs) for foreigners from EU/EEA/EFTA who decide to be employed in the Czech Republic. The process of establishing a business, and the other obligations connected to it, are still complicated in the Czech Republic although it has been simplified significantly in the past few years. A second explanation is that, if foreigners from outside the EU/EEA/EFTA area lose their job, their further stay in the Czech Republic is very limited while, in the case of running a business, this is not so. This is also connected to a third reason that, after the accession of the Czech Republic to the Schengen Area in December 2007, foreigner-entrepreneurs with a trading licence in the Czech Republic also have easy access to other EU member states. 
Figure 8 - Structure of foreigner-entrepreneurs as at June 2010

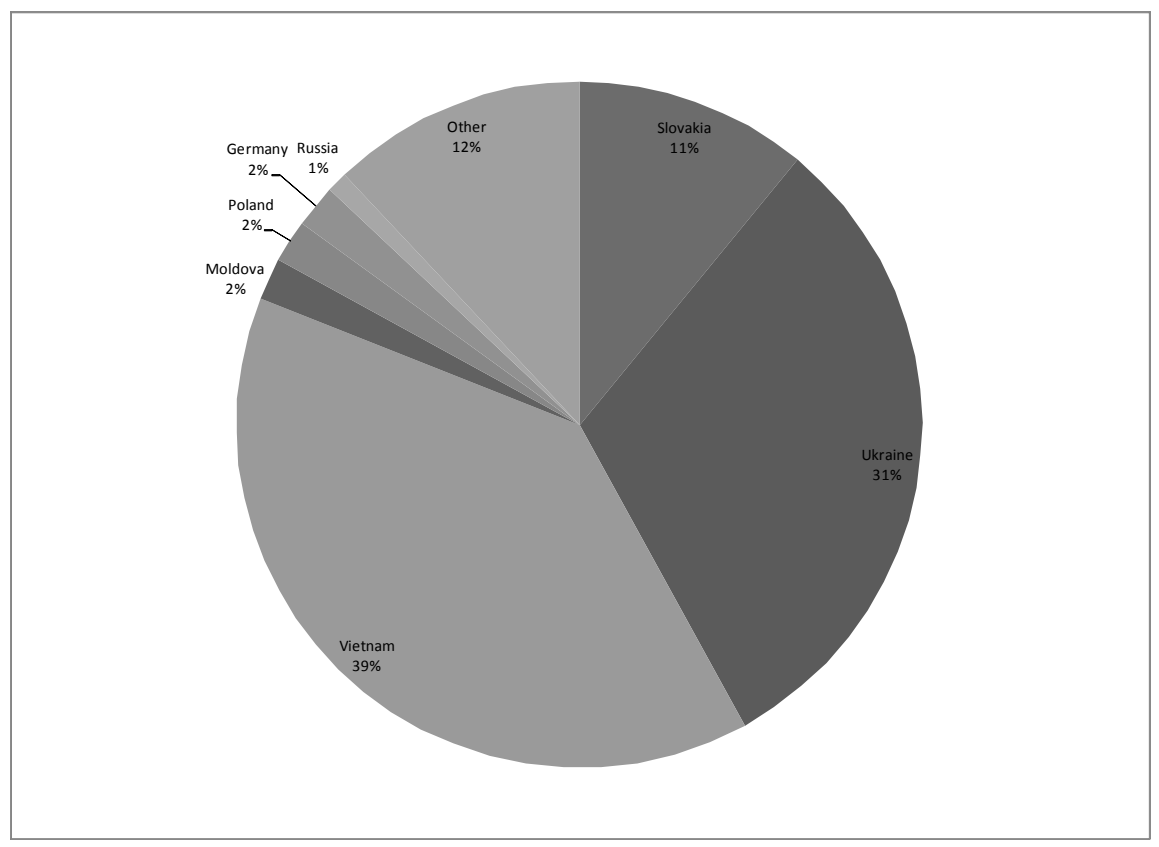

Source: Czech Statistical Office (ČSÚ, 2010), own calculations

From EU/EEA/EFTA member countries, it is citizens of Slovakia that are most frequently engaged in running a business in the Czech Republic, representing $11 \%$ of the total number of foreigner-entrepreneurs. During the economic recession, i.e. between 2008 and the first half of 2010, this rose by more than $10 \%$. The high proportion of entrepreneurs from Slovakia has identical roots as the high share of employees from the same country, i.e. the former common state connected by language and territorial proximity.

The largest share of foreigner-entrepreneurs has, for a long time, been taken by citizens of Vietnam. During the economic recession, their number rose by 2400 , while the number of employees from Vietnam in the same period slumped by almost 13000 . Entrepreneurs from Vietnam are a common feature in the Czech Republic, especially in the area of retail trade. During the economic recession, entrepreneurs coming from Ukraine rose significantly: between 2008 and the first half of 2010, their amount increased by 6800 , or by $32 \%$. In the case of citizens from Ukraine, the attempt to start a business to prevent an exit from the Czech Republic because they have lost their job is an evident explanation. 
Table 3 - Foreigner-entrepreneurs according to country of origin

\begin{tabular}{|l|l|l|l|l|}
\hline & 2008 & 2009 & June 2010 & $\begin{array}{l}\text { Difference } \\
\mathbf{2 0 0 8} / \text { June }\end{array}$ \\
\hline Trading licence holders - total & 77158 & 87753 & 89445 & 12287 \\
\hline EU & 15896 & 17022 & 17738 & 1842 \\
\hline Vietnam & 32139 & 35590 & 34542 & 2403 \\
\hline Ukraine & 21213 & 26223 & 27977 & 6764 \\
\hline Slovakia & 9255 & 9865 & 10243 & 988 \\
\hline Moldova & 1113 & 1559 & 1669 & 556 \\
\hline Poland & 1364 & 1450 & 1528 & 164 \\
\hline Germany & 1361 & 1426 & 1469 & 108 \\
\hline Russian Federation & 1262 & 1336 & 1361 & 99 \\
\hline Bulgaria & 958 & 977 & 1002 & 44 \\
\hline United Kingdom & 760 & 866 & 912 & 152 \\
\hline United States & 579 & 663 & 698 & 119 \\
\hline
\end{tabular}

Source: Czech Statistical Office (ČSÚ, 2010), own calculations

The second significant difference between foreigner-entrepreneurs and foreigneremployees is that, in the period from 2008 until the end of the first half of 2010, the total of foreigner-employees decreased by $23 \%$ while the amount of foreigner-entrepreneurs rose by $16 \%$. If we sought to analyse the dependence of the number of foreigner-entrepreneurs on the rate of unemployment and on the number of vacancies, similarly to what we did in the case of foreigner-employees, we would get different results. In the time of the recession just past, when the unemployment rate grew and the amount of vacancies decreased, the number of entrepreneurs was on the increase. The causes of the different development trends for foreigner-entrepreneurs were explained above.

Programmes of the government in the area of the economic activity of foreigners

The Czech government has adopted two programmes which should have a significant influence on the number of economically active foreigners. The first of these was a scheme to attract particularly skilled foreigners into the Czech Republic via so-called Green Cards. The second programme was labelled 'voluntary repatriation' which was aimed at easing the return to their countries of origin of foreigners who, because of the economic crisis, had lost their jobs in the Czech Republic. 


\section{Green Card}

The Green Card is, in fact, a long-term residence permit in order to work in the Czech Republic at a particular job. The Card should facilitate the arrival on the Czech labour market of foreigners possessing qualifications which are in demand in the Czech Republic. The Green Card is addressed only to foreigners who come from particular specified countries. The foreigner has first to find, from a list of vacancies, a job which cannot be occupied by domestic employees before asking a respective embassy of the Czech Republic for the issue of a Green Card. The embassy must decide, within two months, if the Green Card will be issued to the foreigner in question. The validity of the Green Card is 2-3 years.

The Green Card programme was initiated on 1 January 2009, and it is not possible to say that it has been a success. During the preparation phase of the programme, it was expected that it would be used by thousands of foreigners whereas, in practice, only dozens have actually applied. The government explains the failure of the programme with reference to the economic recession, which became apparent at the end of 2008. A second reason is the lengthy and bureaucratic process of obtaining a Green Card. A third reason for the failure may be some unsuitably chosen countries: among them belong, for example, the United States, Australia, Japan, New Zealand and Canada i.e. countries which are geographically distant and, in addition, economically more advanced than the Czech Republic.

\section{Voluntary repatriation}

In connection with the economic recession, which affected the Czech Republic at the end of 2008 and particularly throughout 2009, a number of foreigners were dismissed from their jobs and found that they had minimal opportunities to find new ones. These people were faced with the cancellation of their work permits and the need to return to their countries of origin. Often, they had run into debt and had no financial means to return. According to responsible organisations, there was a threat of them becoming part of the illegal economy and participating in criminal activities. The government of the Czech Republic, therefore, prepared a programme of "voluntary repatriation'. Under this programme, foreigners could register with the immigration police; they were then provided with the possibility of a return to their country of origin and, in addition, an amount of $€ 500$ (in the first phase of the programme) or $€ 300$ (in the second phase), which should have eased their situation after their return to the country of origin. Approximately 2200 foreigners in total left the Czech Republic under this programme.

\section{Conclusion}

Foreign citizens participate actively in the Czech Republic labour market. They may be active as employees, registered with labour offices; or as entrepreneurs, running a business on the basis of a trading licence. The total number of economically active inhabitants depends on many factors. In this text, three have been analysed. The first was the division of the common state of Czechoslovakia into two independent countries, the Czech Republic and the Slovak Republic, in 1993; while the second was the 
accession of the Czech Republic to the European Union in 2004. Both these factors were linked to a number of legislative changes. Finally, the third factor is the level of economic activity of the Czech economy.

The division of Czechoslovakia had a significant impact on the leading position of the citizens of Slovakia among foreigners on the Czech labour market. Subsequent to the division of the country, their activity on the Czech labour market was by no means restricted.

The accession of the Czech Republic to the European Union resulted in a simplification of the arrival of citizens from EU/EEA/EFTA member countries. Owing to this, their number, either as employees or as entrepreneurs, gradually rose.

The economic situation has also significantly influenced the participation of foreigners in the Czech labour market, especially those who do not come from EU/EEA/ EFTA member countries. The rapid growth of the Czech economy in 2005-2007 was connected with the substantial growth of foreigners in the Czech labour market. The economic recession, which affected the Czech economy mostly during 2009 , led to a dramatic decrease in the number of foreigner-employees. In contrast, in spite of the recession, the number of foreigner-entrepreneurs in the Czech labour market has increased. The programmes of the government which were focused on attracting skilled foreigners or, conversely, on the return of foreigners to their countries of origin, had entirely negligible impacts on the Czech labour market.

\section{References}

Boušková, P (1998) Pracovní migrace cizinců v České republice v 70. až 90. letech Available at: http://aplikace.mvcr.cz/archiv2008/azyl/integrace2/nks01/prispevek4.pdf [last accessed 20 December 2010].

ČSÚ (2010) Cizinci v $\check{C} R$ - Zaměstnanost, datové zdroje Available at: http://www.czso.cz/csu/cizinci.nsf/datove udaje/ciz zamestnanost [last accessed 20 December 2010].

Ministerstvo financí České republiky (2010) Makroekonomická predikce České republiky ríjen 2010 Available at: http://www.mfcr.cz/cps/rde/xbcr/mfcr/MakroPre 2010Q4_komplet_pdf.pdf [last accessed 20 December 2010].

Löster, T (2010) 'Vývoj počtu zahraničních zaměstnanců v ČR v letech 1997 - 2009' FernStat_CZ2010 pp.74-80.

Pavelka, T (2010) 'Cizí státní příslušníci - podnikatelé - na českém trhu práce’ FernStat_CZ2010 pp. 86-91. 